\title{
The Effect of Internal Control on Organizational Performance in the Telecommunications Industry in South South and South East Nigeria
}

\author{
Esther Simon \\ Department of Business Administration and Marketing, Faculty of Management Sciences, Delta State University, \\ Asaba \\ Corresponding author email: esthersimon1981@gmail.com
}

\begin{abstract}
The study focused on effect of admin internal control on performance in telecommunications industry in South South and South East Nigeria. The study employed a descriptive survey research design. Instrument adopted for the study is a structured questionnaire based on simple random sampling method. In addition, interview was also employed to serve as a compliment for the questionnaire. Reliability of the research instrument was tested using the Cronbach Alpha method which revealed that the instrument is reliable. The result of Durbin Watson revealed that the data is free from autocorrelation. Data analysis was done using both descriptive and inferential analysis technique. Descriptive statistics was used to give insight on the respondents profile while inferential statistics was used in the conducting of hypotheses. The two research questions for the study were analyzed using multiple regression model. The study shows that the two null hypotheses were rejected while the two alternative hypotheses were accepted (organization's internal control environment $(p=0.000<0.05, \beta=0.890)$ and risk assessment $(p=0.000<0.05, \quad \beta=0.242)$; the study concluded that organization's internal control environment and risk assessment, has a positive influence on organizational performance. Thus, telecommunications industries that invested more on effective internal control systems are most likely to experience an improved overall performance as compared to those telecoms industries that had a weak internal control system. The study recommended the following among others: management of firms in the telecommunication industries should further study the control environment on possible aspects they might have paid little attention to which might have impacted performance; management should develop additional control activities to sustain and boost the achievement of internal control. Keywords---control systems, internal control, management, organizational performance, telecommunications industry.
\end{abstract}

\section{Introduction}

Several studies have indicated that internal control variables that have an impact on the performance of an organization including the control activities, risk assessment and control environment. Financial performance can be measured by liquidity, efficiency and profit while non-financial performance can be measured by non-monetary variables such as customer satisfaction, defect rates, brand loyalty, first pass yields and employee satisfaction. It can be said that the basic concepts of an organization's risk assessment processes are relevant to both large and small organizations.

Market volatilities can lead to diminished demand, erosion of prices and downturns of foreign exchange rates. Given that organizations deal with public funds, there is need for strong internal control measures to safeguard the funds. Different internal control systems come with different effectiveness levels. Studies carried out by professionals in Europe and north America found out that companies that had strong internal control systems were well developed, better in a competitive market, greatly controlled by government laws, extra conservative, more competent, had high liquidity and profitability and had better management controls (Njeri, 2017). There are majorly four internal control theories that have been advanced namely: the systems, agency, institutional and stakeholder 
theory. Agency theory involves the entrusting of one's obligations to another person to perform services on their behalf. The delegation helps in promoting efficiency and productivity through division of labor. The institutional theory perceives institutions as social structures which have gained higher degree of resilience. According to the institutional theory the structures are made of elements (normative, regulative and cultural-cognitive) that promote legitimacy (Njeri, 2017; Short \& Palmer, 2003; García-Morales et al., 2012). These elements work in association with given resources and activities to enhance stability and the interactive nature of humanity and their environment. The stakeholder (owners) theory, on the other hand, perceives an organization as comprising of stakeholders who benefit or get harmed by the actions of an organization. The stakeholders include stockholders, employees, suppliers, customers regulatory agencies and competitors of the organization. The systems theory is an interdisciplinary theory that investigates a phenomenon using a holistic approach. It considers an observed reality as integrated and interacting in such a way that the individual parts are indistinct because they are interrelated.

According to Mirinaviciene (2014), most researchers are in agreement that internal controls inform good financial reporting and prevention of fraud. However, many organizations put more emphasis on external audits than internal audits. As a result, they focus more on determining whether fraud has occurred instead of using internal controls and audits to prevent any malpractice from occurring in the first place. Organizations lose about 5\% of revenue from fraud every year. Despite the existence of fraud detection techniques such as ratio analysis, regressions analysis, financial ratios, decision trees, neutral networks and transformation of variables, fraud is still difficult to detect since the executives involved have learnt to manipulate results. With the improvement in technology, financial institutions have expanded their operations beyond their domestic borders, which expose them to higher risks, frauds and other irregularities. It is therefore imperative that institutions maintain strong internal controls. Internal control and risk management are fundamental elements of governance of an organization. The two elements are perceived as the foundation to the new strategic business management approach. A study carried out by Saeidi et al. (2015) to look into the coordination of internal control operations and performance effects of a Golestan telecommunication company found a productive interdependence of the company's internal control and performance. Therefore, when an organization implements an effective internal control system, it performance gets improved, both on financial and non-financial aspects.

The objective of the study is to review the literature on the effectiveness of internal control on organizational performance through the use of five internal control components (organization's internal control environment, risk assessment, control activities, information and communication and monitoring), and their resultant effect on organizational performance, using the telecommunications industry (specifically, Airtel, MTN, and 9Mobile) in Asaba, Benin City, (South South) and Onitsha (South East) Nigeria as a case study.

\section{The Problem}

Efficient internal controls create an organization's confidence in its ability to perform or undertake a particular task and prevent errors and losses through monitoring and enhancing organizational and financial reporting processes, as well as ensuring compliance with pertinent laws and regulations. Proper systems have to be put in place in order to discourage errors, fraud and identify mistakes quickly, and, if that fails, management can take corrective action to minimize losses. Owners or managers are responsible for establishing an effective control environment in their organizations, as this is part of their responsibility over the use of organization resources. Because internal control services may have many component purposes, there are increasing calls for better internal control systems. In order to be able to perform, organizations must critically look at customers and all stake holders in business and know how best they are satisfying their needs. Taking a brief historical review on the telecommunications industry in Nigeria, Airtel, which once started as Econet Nigeria has over the years been known for its constant change in management, which among all can be attributed to poor internal control system. In the same way, Etisalat Nigeria lost its brand name to 9Mobile due to factors that can be attributed to poor internal control system. MTN Nigeria has also not been totally free from having their own share, as the company was almost forced out of business as a result of the huge fine that was imposed on them which also can be attributed to poor internal control system. In seeking to enhance accountability and restore investor's confidence, there is need to emphasize the critical role of internal control over organizational performance. These among all have prompted the researcher into researching on internal control and organizational performance, using the telecommunication industry, specifically, Airtel, MTN, and 9Mobile in Asaba, Benin City, (South South) and Onitsha (South East) Nigeria as a case study. 
- to what extent does organization's internal control environment affect organizational performance in the telecommunications industry?

- how does risk assessment affect organizational performance in the telecommunications industry?

\section{Objectives of the Study}

- examine the effect of internal control environment on organizational performance in the telecommunications industry.

- determine the level of risk assessment on organizational performance in the telecommunications industry.

\section{Research Hypotheses}

$\mathrm{HO}_{1}$ : Organization's internal control environment has no significant effect on organizational performance in the telecommunications industry.

$\mathrm{H}_{\mathrm{O} 2}$ : Risk assessment has no significant effect on organizational performance in the telecommunications industry.

\section{Review of Related Literature}

\section{Conceptual Reviews}

\section{Concept of Internal Control}

Internal control can be defined as a set of mechanism designed to motivate an individual or a group towards achievement of a desired objectives (Kirsch, 2002). Internal control should be able to achieve the objective of bringing about cooperation among people with divergent objectives in the organization. Cahill (2006) defines internal control as a system of internal administrative efficiency which often leads to design of a system that will enhance financial check and balance which will support corrective actions intended by the management of the organization and will ensure the primary goal of the organization is achieved.

Transparency International (2006) reported that internal controls are controls developed by organization to generate transparency and avoid corruption. Transparency International (2006) further stated that corruption usually arise as a result of abuse of public office for private gains. Examples includes; Bribery: kickbacks and embezzlement of public funds. Similarly, internal control has been defined as all policies and procedure adopted by the management of an entity to assist in achieving the primary objectives of the management by ensuring that the business is conducted in the most efficient way possible and also ensuring strict adherence to management policies, safeguarding of asset, prevention and detection of fraud and timely preparation of reliable account records (Jacob \& Philip, 2016).

The Committee of Sponsoring Organizations (COSO, 2013) defines internal control as a process, affected by an entity's board of directors, management and other personnel, designed to provide reasonable assurance regarding the achievement of objectives in the following categories: 1. Effectiveness and efficiency of operations. 2. Reliability of financial reporting. 3. Compliance with applicable laws and regulations. Mawanda (2008), defined internal control as measures and processes instituted by management of organizations generally to provide realistic assurance on how the organization's objectives are achieved with particular regards to operational efficiencies, effectiveness and the level of compliance with applicable laws, rules and regulations. They are measures that provide credible financial reporting (Gray, 2008). Ndungu (2013) added that understanding the concept of internal controls is very central for developing a framework for its impact in the organization.

Ntongo (2012) agrees to the assertion that sound internal control facilitates the achievement of objectives. However, to make more meaning he categorized the controls into two main forms. First type is the accounting controls which are controls of safeguarding assets which eventually ensures accuracy in financial records. The second type accordingly, is the operational or administrative controls and they are primarily designed to provide and improve operational efficiency and compliance to policies, laws and procedures. On the contrary, it is noted that the existence of the controls alone cannot ensure the achievement of desired results unless it is combined with enforcement and periodic evaluation to assess the effectiveness. Ming \& Wang (2009) totally agree with this statement but further established that the effectiveness of internal control systems in organizations endorses 
reliability of accounting records. In addition to the above mentioned arguments, an effective internal control system has the potential of preventing fraudulent activities, reduce errors and thereby ensure authenticity of financial reports providing reasonable assurance to stakeholders. Nonetheless, the presence of inherent limitations in the internal control systems affects the credibility (Oppong et al., 2016; Liu et al., 2007; Li et al., 2006).

\section{Components or Attributes of Internal Control}

Internal Controls are to be an integral part of any organization's financial and business policies and procedures. Internal controls consists of all the measures taken by the organization for the purpose of; (1) protecting its resources against waste, fraud, and inefficiency; (2) ensuring accuracy and reliability in accounting and operating data; (3) securing compliance with the policies of the organization; and (4) evaluating the level of performance in all organizational units of the organization. Internal controls are simply good business practices (Kansas State University, n.d).

The Committee of Sponsoring Organizations (COSO) internal control framework consists of five interrelated components or attributes derived from the way management runs a business. According to COSO, these components provide an effective framework for describing and analyzing the internal control system implemented in an organization as required by financial regulations (Securities Exchange Act of 1934 cited in Committee of Sponsoring Organizations (COSO, 2013). Determining whether a particular internal control system is effective is a judgment resulting from an assessment of whether the five components - Organization's Internal Control Environment, Risk Assessment, Control Activities, Information and Communication, and Monitoring - are present and functioning. Effective controls provide reasonable assurance regarding the accomplishment of established objectives (COSO, 2013). The five components or attributes are the following:

Organization's internal control environment: The organization's internal control environment sets the tone of an organization, influencing the control consciousness of its people. Mawanda (2008) asserts that the organization's internal control environment is the foundation for all other components of internal control, providing discipline and structure. Among other things, organization's internal control environment factors include the organizational climate and culture, norms and practices, management's operating style, delegation of authority systems, as well as the processes for managing and developing people in the organization. The organization's internal control environment, as established by the organization's administration, sets the tone of an institution and influences the control consciousness of its people. Norton (2016) suggests that leaders of each department, area or activity establish a local control environment. This is the foundation for all other components of internal control, providing discipline and structure. Organization's internal control environment factors include:

- Integrity and ethical values;

- The commitment to competence;

- Leadership philosophy and operating style;

- The way management assigns authority and responsibility and organizes and develops its people.

Risk assessment: The process of identifying and analyzing risk is an ongoing process and is a critical component of an effective internal control system (COSO, 2013). Attention must be focused on risks at all levels and necessary actions must be taken to manage. Risks can pertain to internal and external factors. After risks have been identified they must be evaluated. Every entity faces a variety of risks from external and internal sources that must be assessed. According to Frazer (2012) a precondition to risk assessment is establishment of objectives and thus risk assessment is the identification and analysis of relevant risks to the achievement of assigned objectives. Albert \& Byaruhanga (2014) argue that risk assessment is a prerequisite for determining how the risks should be managed. Managing change requires a constant assessment of risk and the impact on internal controls. Economic, industry and regulatory environments change and entities' activities evolve. Mechanisms are needed to identify and react to changing conditions.

\section{Elements of Internal Controls}

According to the guidelines issued by the Institute of Chartered Accountants of England and Wales (ICAEW) on Internal Control (Monday et al., 2014; Harris \& Ogbonna, 2001; Chang et al., 2010), the elements of internal control that may be found in many enterprises are mnemonically put as 'PAPAMOSS': 
'P' Physical controls over assets

'A' Arithmetical and Accounting Controls

'P' Personnel Controls

'A' Authorizations and Approvals

' $M$ ' Management Controls

'O' Organizational Controls

'S' Segregation of Duties

'S' Supervisory Controls

Physical controls over assets: These are those procedures and measures set up to secure proper custody over valuable corporate assets. They prevent unauthorized access to these assets. All assets of an organization should be safeguarded at all times especially the valuable and portable assets such as cash, stock and motor vehicle. Security of assets should be designed to ensure that access to assets is limited to authorized persons and no asset is stolen without notice (Monday et al., 2014; Bowen \& Steel, 2010; Elenkov, 2002; Lin et al., 2005).

Arithmetical and Accounting Controls: These controls, which are predominant in the recording function, ensure that all transactions occurring during the period have been authorized, and that they have all been correctly and accurately recorded and processed. There should be a system of checks on the arithmetic accuracy of the accounts kept in respect of transactions e.g. extraction of balances, to check the accuracy of all postings during a given period, establishment of control accounts of creditors and debtors etc. This example also includes checking the arithmetical and accuracy of calculations and maintaining and checking control totals (Monday et al., 2014).

Personnel Controls: No matter how well a system is designed, its efficient and effective functioning will depend on the operators. Controls are therefore necessary to ensure that personnel have capabilities commensurate with their responsibilities (Umar \& Dikko, 2018). These controls, known as personnel controls, provide a framework for ensuring an efficient selection and training procedure for staff. There should be qualification system to ensure that a capable staff is allocated to a particular duty and is sufficiently motivated to ensure effective and efficient performance of his duty with complete integrity.

Authorizations and Approvals: These are those controls, which specify the persons responsible for authorizing and approving transactions and the limits of such authority. All transactions should be authorized and approved by responsible officials before the organization is financially committed. Such authority should be clearly specified in writing and the limit of authority or responsibility clearly defined (Umar \& Dikko, 2018).

Management Controls: These are those controls characteristically executed by top management on a periodic basis as against a daily basis. Conceivably, they include periodic reviews of management accounts and comparison thereof with budgets and other special reviews. Some writers call management controls overriding controls. It is the responsibility of management to establish control for day-to-day operation of the affairs of the organization and this will include supervisor controls, internal audit functions, review of management accounts and comparison of actual result with budget and other review procedures (Monday et al., 2014).

Organizational Controls: These are those controls, rules, regulations and procedures which specify the organizational plan or structure, define roles and allocates responsibilities; and identify lines of reporting for all aspects of the enterprises' operations. Responsibilities should be allocated to staff according to experience and proficiency and the line of reporting should be clearly indicated.

Segregation of Duties: They are those controls, which ensure that separate individuals or groups of individuals carry out the main functions of an organization of authorization, executive, custody and recording. It is believed that the separation of these critical duties will minimize the inherent risk of fraud or errors and increase the element of checking within the system. This is to ensure that no one person is responsible for all aspects of a transaction. In other words, the job should be arranged in such a way that the work of one person is complementary to that of another or independently checked by another person so that fraud and error may be minimized or early detection maximized. Involvement of more individuals reduces the risk of accidental error and deliberate fraud (Monday et al., 2014).

Supervisory Controls: These are controls over day-to-day activities of the organization, which ensure that the work of less experienced staff are reviewed and controlled by independent, more senior and experienced staff. This is part of the internal check. The checker should have a thorough knowledge of the job. In addition to the above control (PAPAMOSS), the other categories are (AB) which is now known as "PAPAMOSSAB" (Monday et al., 2014). The other two (2) categories according to the authors are explained thus:

Acknowledgment of performance: This is the control that specifies that for each activity performed, the person that performs the activity must acknowledge in writing that he performed the activity. The level of acknowledgment 
varies from simply signing-off with date or doing it with brief comment on the activity carried out. It is expected that somebody will not acknowledge a performance he is not sure of. For example, if invoice calculations have to be checked, the checker should initial each invoice. Acknowledgment of performance not only allows blame to be ascribed but also has a powerful psychological effect (Monday et al., 2014).

Budgeting Controls: These are controls that set targets for activities, volumes and other financials of the organization. Targets are set for the number of new customers for the marketers, for expenses, sales, production, stock levels, purchases, fixed assets acquisition etc. These targets act as goal motivation for the employees. They also form reasonable basis for assessing staff efforts. A common control technique applied in business is the use of budgets, which can be defined as a quantitative plan of action. Budgets having been agreed can be compared with actual performance and differences investigated.

\section{Brief History of the Telecommunications Industry in Nigeria}

Coming to the telecommunications industry in Nigeria, Etisalat (a telecommunications services provider based in the Emirates) had major problems with loans it was unable to repay which led to the termination of its management agreement with its Nigerian arm, and further led to it pulling out all its shares from the country and gave 3 weeks to phase out the brand that resulted to the adoption of 9mobile (Financial Nigeria, 2017). Consequently, a major and earlier observed trend is that of Airtel Nigeria today, which was once known as Econet Nigeria, and was one of the three companies that won the GSM license auction (and the other two being MTN Nigeria and MTEL) changed hands to Vodacom due to political shenanigans and corruption practices. In less than 2 months after the deal was reached, the company (Vodacom) decided to pull out and changed hands to V-mobile as a result of heavy charges and some corrupt practices. The network (Vmobile) also survived for the next 2 years till it was bought over by Celtel. Again, Celtel couldn't survive more than 2 years before it folded and sold out its shares to Zain. Still unable to break more than 2 years, Zain Nigeria was finally sold to Bharti Airtel (Taiwo, 2015). Taking a close look at possible cause and effect, one could attribute the constant change of hands in management to lack of good internal control system. Also, MTN has not really been completely free from having its own share, as the South African company was almost forced out of business in Nigeria by the huge fine placed on them on failure to disconnect unregistered subscriber SIM (Punch, 2018). From the foregoing, it can be said that a faulty internal control system can have a negative effect on organizational performance.

\section{Organizational Performance}

The word "performance" means to carry out, to render or to do. It is the act of accomplishing, fulfilling or executing. In a broader sense, it means the accomplishment of a task which is measured against a given set of standards of completeness, speed, cost and accuracy. In organizational settings, the activities of an organization are measured against past performance or projected cost efficiency, accountability or management responsibility (Kohlar, 2003). Financial performance is a measure of how well an organization is using its assets to generate revenues. It measures an organizations financial situation over a specified duration. Varied methods are used in measuring financial performance; however, all the specified measures are cumulatively applied. Among the entries in a fiscal budget that can be used include cash flow from operations and operating income.

There are five main financial performance indicators including Gross profit margin, net profit, net profit margin, aging accounts receivables and current ratios. The gross profit margin ensures that the establishment prices its services appropriately. It is obtained by dividing the difference between revenue and cost of services sold by the revenue earned. Net profit margin is the amount of money left over after a firm has paid all the bills. It is obtained by subtracting the total expenses from the total revenue.Net profit margin shows what percentage of revenue is profit. Aging accounts receivable is a report listing unpaid customer invoices by date ranges. It is a tool that shows the effectiveness of credit and collection functions. The current ratio indicates the presiding ability of the institution to cater to all its financial needs and is obtained by dividing the current assets by the current liabilities (Hales, 2005). Non-financial performance is a measure of value of an organization using non-monetary units.

The main non-financial performance indicators are: customer satisfaction, employee satisfaction, innovation and market share. Customer satisfaction is the state of mind that the customers have about an organization while employee satisfaction describes whether employees are contented and happy at work (Ponte, 2009). Innovation describes the development of new products or services and is measured through innovation sales rate which is a measure of the percentage of sales from new products or services. Market share is the percentage of a market that is accounted for by an organization. It is worth noting that non-financial performance indicators can vary from one 
organization to the other. To measure the non-financial performance of an organization, the management comes up with a methodology which involves identifying key performance drivers and designing of the most relevant Key Performance Indicators (KPIs). A decision tree is used to develop non-financial performance measures using key questions that the managers need to answer. Other non-financial performance measures of success that an organization can come up with include brand recognition, internal business process, cycle time and education and training (Ponte, 2009).

\section{Internal Control Systems and Organizational Performance}

With the increase in the number of organizational branches, internal control and governance becomes essential in aligning the interests of the subsidiaries with those of their headquarters. In the absence of such control, the subsidiaries may decide to maximize their interests undermining the long-term performance of the organization. At the same time, the management of the parent company may also take decisions that reduces the shareholders' value hence the need for monitoring and control at both levels. Both external and internal corporate governance mechanisms have evolved with time to bond, control and monitor the management. These governance mechanisms include managerial labor markets, capital markets, investors, regulation and the board of directors who aligns the interest of management and stockholders. The parent-subsidiary governance structure is governed by factors in the host or home country. The factors include legal, cultural, regulatory and political systems, global capital, historical patterns of the countries, labor, global institutional investors and managerial markets. Other important factors include strategy of the company, the size and the industry in which the subsidiary is operating. Beeler et al. (1999) asserts that internal control has a broader purpose which includes exploring the control problems that are caused by lower revenues and explains the interrelationship between fraud and material weakness. Internal control is therefore an independent appraisal of managerial performance.

Effective internal control system is unequivocally correlated with an organizations success and it involves reviewing of the authenticity of the operational activities, the controls safeguarding the organization assets, assessment of compliance of employees to the managerial laws and regulations, following operational guides, and an assessment of the efficiency of achieving the team objectives (Fadzil, 2005). Singleton et al. (2016) classifies internal controls into three forms of controls; the preventive, normative and detective controls. Preventive controls give an insight of problems that are likely to occur and institutes adjustments before the problems are experienced. Detective controls detect and reports errors, omissions or malicious acts, while corrective controls ensure the effects of the threats are minimized. Dineshkumar \& Kogulacumar (2013) studied internal control system of the Sri Lanka Telecom Limited the impact of the controls on its performance. The study found that $76 \%$ of Sri Lanka Telecom had a high level of internal auditing procedures. There were no rules and regulations to monitor organization's internal control environment properly hence the auditing rules were not adhered to during the exercise. By efficiently applying the internal control resources, the level of efficiency gets moderated subsequently. On profitability, the study found that $27 \%$ of the company's strategic level had low profitability, $20 \%$ of the company's tactical level had low level of profitability while $53 \%$ of the operational level had high profitability. Overall, $62 \%$ of the organization had high level of performance hence $62 \%$ of the organizational goals were achieved. Mire (2016) researched on the effects of a control system on the levels organizational performance of remittance corporations in Mogadishu. The findings of the study showed a variation of $99.3 \%$ on the performance of the organizations as a result of changes in risk assessment, control activity and organization's internal control environment at $95 \%$ confidence interval.

Kinyua (2016) carried out a study on how the financial performance of some companies included in the Nairobi Stock Exchange is affected by the set of internal control systems. The study used descriptive research design and employed both qualitative and quantitative approach. It targeted 372 senior managers managing 62 companies that are quoted in the NSE. The researcher tested whether risk management, internal audit function, corporate governance, internal control activity and organization's internal control environment had an impact on the performance of the companies using multiple regression models. Using the Pearson correlation coefficient, the researcher showed that risk management function was the leading variable with the highest influence at 0.55 . Corporate governance followed closely at 0.554 , control activity and internal control at 0.457 and 0.420 respectively while internal audit function came fifth at 0.341 .

\section{Risk Assessment and organizational performance}

Risk assessment is among the component of internal control. Risks threatens the achievement of objectives. An entity's risk assessment process is the process of identifying and responding to business risks and the results thereof 
(Albert \& Byaruhanga, 2014). Risk Assessment is also defined as identification of potential errors and implements procedures, policies, and control to detect those errors and prevent them. Risk assessment can also be the identification and analysis of risks relevant to the achievement of objectives (Frazer, 2012). In order word risk assessment is the process of detecting, assessing and determining how to succeed these things. Both external and internal risks could prevent the achievement of established objectives at every level in an organization. According to COSO (1992) every organization, be it private or public, large or small, faces risks from both external and internal sources that must be assessed. Therefore, management should take necessary actions to prevent these risks. But, sometimes management cannot avoid the risk from occurring. In these situations, management should determine whether to accept the risk, reduce it up to the acceptable levels, or avoid. An organization principally establishes an early warning system to determine risks with low-probability, and take the necessary steps to minimize or remove such risks (Hayali et al., 2013).

Because economic, industry, regulatory and operating conditions will continue to change, mechanisms are needed to identify and deal with the special risks associated with the change. It is therefore important for management to determine and assess the risk level it can accommodate and for that matter ensures it achieve its goals. In line with this, management designs and operates adequate internal control to ensure efficient and effective use of resources and comply with regulations and laws. Norton (2016) identified the following risk assessment principles which organization should consider.

- The organization should assess and identifies changes that could significantly impact the system of internal control. Control operations consist of a variety of activities, according to Frazer (2012) these activities are; Physical controls (such as controlling whether necessary measures are taken in order to reach assets and records or not, controlling the physical presence or absence of assets, comparison between accounting records and periodic inventory); Performance assessment (to confer between the actual operations and objectives of a corporate); Information processing controls; Should also; assess changes in leadership; assess changes in the business model; assess changes in the external environment; Segregation of duties (for instance registration procedures, and custody of assets; assigning different employees with different tasks such as procurement of assets) (Janvrin et al., 2012; Norton, 2016).

- The organization should consider the potential for fraud in assessing risks to the achievement of its objectives. The organization should specify objectives with sufficient clarity to enable the identification and assessment of risks relating to objectives. Should; consider toleration for risk and required level of precision/materiality comply with externally established standards and frameworks and laws and regulations reflect management's choices; reflect entity activities; include operations and financial performance goals; form basis for committing of resources. Should also consider various ways that fraud can occur; consider risk factors; assess incentive and pressures; assess opportunities; assess attitudes and rationalizations (Janvrin et. al., 2012; Norton, 2016).

- The organization should identify risks across the entity to the achievement of its objectives and should also analyze those risks as a basis for determining how the risks should be managed. This can be achieved through the following attribute; involve appropriate levels of management; division, subsidiary, functional levels, and operating unit; analyze both external and internal factors; the determine how to respond to risks, and estimate the significance of risks identified (Janvrin et. al., 2012; Norton, 2016).

- The organization specifies objectives with sufficient clarity to enable the assessment and identification of risks relating to objectives. Attributes: consider toleration for risk and required level of precision/materiality; comply with externally established standards and frameworks and laws and regulations; reflect management's choices; reflect entity activities; include operations and financial performance goals; form basis for committing of resources (Janvrin et. al., 2012; Norton, 2016).

\section{Theoretical Framework}

The study was hinged on Agency Theory because of the relationship attributes involving heterogeneous groups. The Agency theory was developed in 1976 by Jensen and Meckling. This theory is an agency relationship as a contract under which one or more persons (the principal(s)) engage another person (the agent) to perform some service on their behalf which involves delegating some decision-making authority to the agent. Agency theory analyses the relationship between two parties: investors and managers. The agent (manager) undertakes to perform certain duties for the principal (investors) and the principal undertakes to reward the agent. As such, the theory describes firms as necessary structures to maintain contracts, and through firms, it is possible to exercise control which minimizes 
opportunistic behavior of agents (Mwangi, 2012). According to the theory, in order to harmonize the interests of the agent and the principal, a comprehensive contract is written to address the interest of both the agent and the principal. The agent-principal relationship is strengthened more by the principal employing an expert and systems (auditors and control systems) to monitor the agent (Jussi \& Petri, 2004).

For the relationship to work, the principal has to trust the agent and assume that the agent will work in the principals' best interest. However, due to self-interest and information asymmetries, a principal may not have reasons to trust an agent and will need to put in place mechanisms to ensure the delegate's interests merge with their own. Auditing is the mechanism that most organizations use to ensure the agent's interests align to those of the organization. The use of audit to resolve agent-principal conflict complicates the matter since auditors are seen as agents of the directors. Other stakeholders such as the shareholders and the public may not trust the auditors and might be concerned about who audits the auditors. Drawing from this theory, the researcher finds the need for organizations to have strong internal control measures and systems to ensure the interests of all the stakeholders are well safeguarded. Donaldson (1990) criticized the theory for having methodology individualism, regressive simplification, and narrowly-defined motivation model, disregard of other research, governance defensiveness and wrong ideological framework. Agency theory assumes that individuals are rational and obey the economic model of human behavior. Donaldson argues that individual activity should not be considered as equivalent to organizational activity. Additionally, the fundamentals of agency theory are information decentralizations, divergence in attitudes toward risks and goals' divergences. In the absence of information asymmetry and assumptions of conflicting interests, the agency theory becomes trivial and uninteresting scientifically.

This theory is applicable to this study simply because internal control is one of many mechanisms used in business to address the agency problem by reducing agency costs that affects the overall performance of the relationship as well as the benefits of the principal (Muhunyo and Jagongo, 2018). Internal control enhances the provision of additional information to the principal (shareholder) about the behavior of the agent (management) reduces information asymmetry and lowers investor risk and low revenue.

\section{Empirical Studies}

The study of Monday et al. (2014) investigated the effect of internal controls on the operating performance of small businesses in Lagos Metropolis. Primary data were employed through structured questionnaire administered to 200 small businesses selected using convenience sampling. Based on Committee of Sponsoring Organization Tread way Commission (COSO) updated framework, six determinants of internal control that include control environment, risk assessment, control activities, information and communication, monitoring, and information technology were examined to determine their influence on the financial and operational performance of small businesses. Frequency counts, percentage, and multiple regressions were used to analyze the data obtained from the distributed questionnaire. The results showed that these determinants have significant effect on the efficiency of operations of the selected small businesses, which consequently enhanced their profitability. The study concluded that internal controls, grounded in the COSO Model, have significantly positive effects in small business profitability and survivability. Thus, this study recommended that managers/owners of small businesses should be attentive to the issues of internal control in order to maximize the business potential and minimize the risk of fraud, error and loss.

The study of Oppong, et al. (2016) examines the current level of internal controls operated by seven faith-based NGOs and how that is affecting their performance. Primary data for the study was obtained using self-administered structured questionnaire and the Statistical Packages for Social Sciences (SPSS 20.0 version) was used to analyze the data. The study found that internal control systems significantly enhances the performance of the faith-based NGOs, in two aspect; economy and efficiency but does not necessarily make the them effective. Again, it was found that existing internal control systems functioned satisfactorily in four components of the COSO model except risk assessment where the procedures were found to be very weak. It was recommend that Management of faith-based NGOs should have holistic measures in place to constantly assess its effectiveness and impact on operations. Moreover, the management should institute a rigorous risk management framework which will be able to detect all risk inherent in the internal control system to improve efficiency.

The study of Umar \& Dikko (2018) examined the effect of internal control systems on the performance of commercial banks in Nigeria. A survey method was employed and the study used stratified random sampling, in which a total of 382 questionnaires were administered to either staff of operations, marketing, or security department in the Nigerian commercial banks. The questionnaire was a 5 point Likert-scale type while the data collected was analyzed using Statistical Package for the Social Sciences (SPSS) version 23 (v23) and Smart PLS 3. The findings of the study revealed that there was a positive and significant relationship between the four components of internal 
control (control environment, control activities, monitoring and risk assessment) and bank performance. While information and communication were found to have an insignificant positive relationship with bank performance. The study recommended that future research should add other additional variables like risk culture, corporate governance. Likewise, control variable (s) such as bank size, bank age, etc. could also be considered by future researchers.

\section{Tools and Methods}

This study is a survey design that followed the descriptive research approach. The objective of this study and the nature of the data gathered determined the appropriateness of the descriptive method that was adopted for this research. Hence, with prior knowledge of the problem, the descriptive research approach allows the study to be structured and pre-planned (Malhotra, 2007).

Table 1

The population of the study comprised staff and members of Airtel, MTN, and 9 Mobile in Asaba, Benin City, (South South) and Onitsha (South East) Nigeria. The choice of these locations is based on accessibility and convenience.

\begin{tabular}{ll}
\hline Name of Organization & Number of Employees \\
\hline AIRTEL & 247 \\
MTN & 281 \\
9MOBILE & 203 \\
Total & 731 \\
\hline
\end{tabular}

Sample Size

The Yamane's formula was used to determine a sample size that is representative of the population under study that gave 259 which was adopted as the sample size.The study employed a simple random sampling technique (probabilistic sampling) whereby all members of the sample had an equal chance of being selected. This was done by using well-structured questionnaires in a five point Likert scale responds format with extremes ranging from strongly agree to strongly disagree. This raised important questions necessary for the ascertainment of fact required for the study. The questionnaire was divided into section A and B.

To establish reliability of the study, Cronbach's coefficient alpha was used to test reliability or to access the quality of the measurement. An acceptance level of 0.700 of Cronbach's alpha was used to test for internal consistency for the study constructs. Data for the study were collected, analyzed and presented using descriptive statistics as well as inferential statistical tools. Descriptive statistics in form of percentages, frequencies and means were employed to provide information on demographic variables and responses to questionnaire items; correlation coefficient and multiple regression analysis was used to test the two hypotheses formulated The Statistical Package for Social Science (SPSS) software version 21 for windows aided in data analysis.

\section{Result and Discussion}

Research Question One: To what extent does organization's internal control environment affect organizational performance in the telecommunications industry? 
Table 2

Showing Control Environment Question from number 1-4

S/N Organization's Internal Control Environment

$\begin{array}{lll}\text { SD } & \text { D } & \text { U } \\ 1 & 2 & 3\end{array}$

$\begin{array}{lll}\mathrm{A} & \mathrm{SA} & \dot{\mathrm{X}} \\ 4 & 5\end{array}$

1. My organization has positive control environment such as integrity and morale that management and employees safeguard to support administrative control and awareness

$\begin{array}{cc}0 & 2 \\ (0 \%) & (0.8 \%)\end{array}$

$\begin{array}{cc}9 & 25 \\ (3.7 \%) & (10.4 \%)\end{array}$

2. The control activities in my organization (such as authentication, assurance, verifications, and performance review) assist to implement the management guidance and that such control activities are effective and efficient in achieving organizational objectives

3. My organization makes efforts to attract, develop, and retain the trusted and efficient employees which contribute in achieving the internal control objective

$\begin{array}{cccccc}0 & 2 & 3 & 89 & 147 & \\ (0 \%) & (0.8 \%) & (1.2 \%) & (36.9 \%) & (61 \%) & 4.58 \\ & & & & & \\ & & & & & \\ & & & & & \\ 2 & 0 & 38 & 51 & 150 & \\ (38 \%) & (0 \%) & (15.8 \%) & (21.2 \%) & (62.2 \%) & 4.44 \\ & & & & & \\ & & & & & \\ 0 & 0 & 20 & 79 & 142 & \\ (0 \%) & (0 \%) & (8.3 \%) & (32.8 \%) & (58.9 \%) & 4.51 \\ & & & & & \mathbf{4 . 5 9}\end{array}$

Source: Researcher's Field survey (2020)

Table 2 above captures responses on effect of organization's internal control environment on organizational performance. Result showed that a substantial number of the respondents $(95.5 \%)$ indicated agreement that their organization has positive control environment such as integrity and morale that management and employees safeguard to support administrative control and awareness, $3.7 \%$ of the respondents were undecided if their organization has positive control environment such as integrity and morale that management and employees safeguard to support administrative control and awareness while $0.8 \%$ of the respondents expressed disagreements for this item respectively. The mean score for this item (4.80) implies that the respondents (employees in the Nigerian telecoms industry) are very much in agreements that their organization has positive control environment such as integrity and morale that management and employees safeguard to support administrative control and awareness.

For the item "The control activities in my organization (such as authentication, assurance, verifications, and performance review) assist to implement the management guidance and that such control activities are effective and efficient in achieving organizational objectives." More than half of the respondents $(97.9 \%)$ indicated agreement to this item, $1.2 \%$ were uncertain while $0.8 \%$ expressed disagreements respectively. The mean score (4.58) for this item implies that the respondents (employees in the Nigerian telecoms industry) strongly agreed that the control activities in their organization (such as authentication, assurance, verifications, and performance review) assist to implement the management guidance and that such control activities are effective and efficient in achieving organizational objectives.

For the item "My organization makes efforts to attract, develop, and retain the trusted and efficient employees which contribute in achieving the internal control objective" more than three quarter of the respondents $(83.4 \%)$ indicated agreements for this item, 38\% expressed disagreements while $15.8 \%$ where uncertain respectively. The mean score of 4.44 for this item implies agreement by the respondents that their organization makes efforts to attract, develop, and retain the trusted and efficient employees which contribute in achieving the internal control objective. A substantial number of the respondents (91.7\%) indicated agreements that their organization has internal control tools on human resources to evaluate the level of productivity, effectiveness and efficiency of its human resources, $8.3 \%$ of the respondents were uncertain while none of the respondents expressed disagreement for this item 
respectively. The mean score of 4.51 for this item suggest a strong agreement by the respondents that their organization has internal control tools on human resources to evaluate the level of productivity, effectiveness and efficiency of its human resources. The mean of means (4.59) suggest a conclusive judgment that the respondents (employees in the telecommunications industry in South South and South East Nigeria) are very high for organization's internal control environment on organizational performance.

Research Question Two: How does risk assessment affect organizational performance in the telecommunications industry?

Table 3

Showing Risk assessment Question from number 5-8

\begin{tabular}{|c|c|c|c|c|c|c|c|}
\hline $\mathrm{S} / \mathrm{N}$ & Control Environment & $\begin{array}{l}\text { SD } \\
1\end{array}$ & $\begin{array}{l}\mathrm{D} \\
2\end{array}$ & $\begin{array}{l}\mathrm{U} \\
3\end{array}$ & $\begin{array}{l}\text { A } \\
4\end{array}$ & $\begin{array}{l}\text { SA } \\
5\end{array}$ & $\dot{\mathrm{x}}$ \\
\hline 5. & $\begin{array}{l}\text { My organization identifies risks that affect } \\
\text { achievement of objectives in a timely manner }\end{array}$ & $\begin{array}{c}0 \\
(0 \%)\end{array}$ & $\begin{array}{c}0 \\
(0 \%)\end{array}$ & $\begin{array}{c}5 \\
(2.1 \%)\end{array}$ & $\begin{array}{c}22 \\
(9.1 \%)\end{array}$ & $\begin{array}{c}214 \\
(88.8 \%)\end{array}$ & 4.87 \\
\hline 6. & $\begin{array}{l}\text { My organization has in place mechanisms of } \\
\text { mitigating critical risks that may arise during the of } \\
\text { course doing business }\end{array}$ & $\begin{array}{c}0 \\
(0 \%)\end{array}$ & $\begin{array}{c}3 \\
(1.2 \%)\end{array}$ & $\begin{array}{l}3 \\
(1.2 \%)\end{array}$ & $\begin{array}{c}70 \\
(29 \%)\end{array}$ & $\begin{array}{l}165 \\
(68.5 \%)\end{array}$ & 4.65 \\
\hline 7 & $\begin{array}{l}\text { Management has defined appropriate objectives for } \\
\text { the organization }\end{array}$ & $\begin{array}{l}2 \\
(0.8 \%)\end{array}$ & $\begin{array}{c}0 \\
(0 \%)\end{array}$ & $\begin{array}{c}25 \\
(10.4 \%)\end{array}$ & $\begin{array}{c}44 \\
(18.3 \%)\end{array}$ & $\begin{array}{c}170 \\
(70.5 \%)\end{array}$ & 4.58 \\
\hline 8. & $\begin{array}{l}\text { Management has a criteria for ascertainment of } \\
\text { which fraud-related risks to the organization are } \\
\text { most critical }\end{array}$ & $\begin{array}{c}1 \\
(0.4 \%)\end{array}$ & $\begin{array}{c}0 \\
(0 \%)\end{array}$ & $\begin{array}{c}18 \\
(7.5 \%)\end{array}$ & $\begin{array}{c}60 \\
(24.9 \%)\end{array}$ & $\begin{array}{l}162 \\
(67.2 \%)\end{array}$ & 4.59 \\
\hline & Mean of means & & & & & & 4.67 \\
\hline
\end{tabular}

Source: Researcher's Field survey (2020)

Table 3 captures responses on effect of risk assessment on organizational performance of telecommunications industry. Result showed that a substantial number of the respondents $(97.9 \%)$ indicated agreements that their organization identifies risks that affect achievement of objectives in a timely manner, $2.1 \%$ were undecided while none of the respondents expressed disagreements for this item respectively. The mean score of 4.87 for this item implies a strong agreement by the respondents that their organization identifies risks that affect achievement of objectives in a timely manner.

For the item "My organization has in place mechanisms of mitigating critical risks that may arise during the course of doing business" majority of the respondents $(97.5 \%)$ indicated agreements to this item $1.2 \%$ were undecided while $1.2 \%$ expressed disagreements for the item respectively. The mean score (4.65) for this item suggest that the respondents are very much in agreement that their organization has in place mechanisms of mitigating critical risks that may arise during the course of doing business.

For the item "Management has defined appropriate objectives for the organization" more than four fifth of the respondents $(88.8 \%)$ indicated agreements to this item, $10.4 \%$ were undecided while $0.8 \%$ expressed disagreements respectively. The mean score of 4.58 for this item implies that the respondents are strongly in agreements that management has defined appropriate objectives for the organization.

For the item "Management has a criteria for ascertainment of which fraud-related risks to the organization are most critical" a substantial number of the respondents $(92.1 \%)$ indicated agreements to this item, $7.5 \%$ were undecided while $0.4 \%$ expressed disagreements for this item respectively. The mean score of 4.59 for this item implies that the respondents are very much in agreement that management has a criteria for ascertainment of which fraud-related risks to the organization are most critical.

The mean of means (4.67) suggest a conclusive judgment that the respondents (employees in the telecommunications industry in South South and South East Nigeria) are high for risk assessment on organizational performance. 
Table 4

Showing organizational performance Question from number 9-12

\begin{tabular}{|c|c|c|c|c|c|c|c|}
\hline $\mathrm{S} / \mathrm{N}$ & Organizational Performance & $\begin{array}{l}\text { SD } \\
1\end{array}$ & $\begin{array}{l}\mathrm{D} \\
2\end{array}$ & $\begin{array}{l}\mathrm{U} \\
3\end{array}$ & $\begin{array}{l}\text { A } \\
4\end{array}$ & $\begin{array}{l}\text { SA } \\
5\end{array}$ & $\dot{\mathrm{x}}$ \\
\hline 9. & $\begin{array}{l}\text { Organization's internal control environment is a } \\
\text { positive catalyst to organizational performance }\end{array}$ & $\begin{array}{c}0 \\
(0 \%)\end{array}$ & $\begin{array}{c}2 \\
(0.8 \%)\end{array}$ & $\begin{array}{c}8 \\
(3.3 \%)\end{array}$ & $\begin{array}{c}23 \\
(9.5 \%)\end{array}$ & $\begin{array}{c}208 \\
(86.3 \%)\end{array}$ & 4.81 \\
\hline 10. & $\begin{array}{l}\text { Risk assessment ensures the achievement of } \\
\text { established objectives at every level in the } \\
\text { organization }\end{array}$ & $\begin{array}{c}0 \\
(0 \%)\end{array}$ & $\begin{array}{l}3 \\
(1.2 \%)\end{array}$ & $\begin{array}{l}3 \\
(1.2 \%)\end{array}$ & $\begin{array}{c}85 \\
(35.3 \%)\end{array}$ & $\begin{array}{c}150 \\
(62.2 \%)\end{array}$ & 4.59 \\
\hline 11. & $\begin{array}{l}\text { Good information and communication system } \\
\text { enhances organizational performance }\end{array}$ & $\begin{array}{c}2 \\
(0.8 \%)\end{array}$ & $\begin{array}{c}0 \\
(0 \%)\end{array}$ & $\begin{array}{c}34 \\
(14.1 \%)\end{array}$ & $\begin{array}{c}47 \\
(19.5 \%)\end{array}$ & $\begin{array}{l}158 \\
(65.6 \%)\end{array}$ & 4.49 \\
\hline 12. & $\begin{array}{l}\text { Monitoring has been employed as a tool to } \\
\text { continually make sure organizational objectives are } \\
\text { achieved }\end{array}$ & $\begin{array}{c}1 \\
(0.4 \%)\end{array}$ & $\begin{array}{c}0 \\
(0 \%)\end{array}$ & $\begin{array}{c}19 \\
(7.9 \%)\end{array}$ & $\begin{array}{c}74 \\
(30.7 \%)\end{array}$ & $\begin{array}{c}147 \\
(61 \%)\end{array}$ & 4.52 \\
\hline & Mean of means & & & & & & 4.60 \\
\hline
\end{tabular}

Source: Researcher's Field survey (2020)

Table 4 shows responses of respondents on organizational performance. Result revealed that a substantial number of respondents (95.8\%) indicated agreements that organization's internal control environment is a positive catalyst to organizational performance, $3.3 \%$ were uncertain if control environment is a positive catalyst to organizational performance while $0.8 \%$ of the respondents expresses disagreements for this item respectively. The mean score of 4.81 for this item implies a strong agreement by the respondents that control environment is a positive catalyst to organizational performance.

For the item "Risk assessment ensures the achievement of established objectives at every level in the organization" majority of the respondents $(97.5 \%)$ indicated agreements to this item, $1.2 \%$ were uncertain while $1.2 \%$ expressed disagreement for this item respectively. The mean score of 4.59 for this item implies a strong agreement by the respondents that risk assessment ensures the achievement of established objectives at every level in the organization.

For the item "Good information and communication system enhances organizational performance" more than three quarter of the respondents $(85.1 \%)$ indicated agreements to this item, $14.1 \%$ were undecided while $0.8 \%$ expressed disagreements for this item respectively. The mean score of 4.49 for this item implies that the respondents are in agreement that good information and communication system enhances organizational performance.

For the item "Monitoring has been employed as a tool to continually make sure organizational objectives are achieved" a substantial number of the respondents (91.7\%) indicated agreements to this item, $7.9 \%$ were uncertain while $0.4 \%$ expressed disagreements for this item respectively. The mean score of 4.52 for this item implies a strong agreements by the respondents that monitoring has been employed as a tool to continually make sure organizational objectives are achieved.

The mean of means (4.60) suggest a conclusive judgment that the respondents (employees in the telecommunications industry in South South and South East Nigeria) are very high in organizational performance.

\section{Correlation Coefficient}

A correlation analysis was performed to establish a relationship among variables of the study. The correlation test results are shown in figure Table 5. 
Table 5

Correlation coefficient between variables for the study

\begin{tabular}{|c|c|c|c|c|c|c|c|}
\hline \multirow{3}{*}{$\mathrm{CE}$} & Pearson Correlation & $\begin{array}{ll}\text { CE } & \\
& 1\end{array}$ & $\begin{array}{l}\text { RA } \\
.792^{* *}\end{array}$ & $\begin{array}{c}\text { CACT } \\
.842^{* *}\end{array}$ & $\begin{array}{l}\text { IC } \\
.827^{* *}\end{array}$ & $\begin{array}{l}\text { MON } \\
.940^{* *}\end{array}$ & $\begin{array}{l}\text { OP } \\
.966 * *\end{array}$ \\
\hline & Sig. (2-tailed) & & .000 & .000 & .000 & .000 & .000 \\
\hline & $\mathrm{N}$ & 241 & 241 & 241 & 241 & 241 & 241 \\
\hline \multirow{3}{*}{ RA } & Pearson Correlation & $.792^{* * *}$ & 1 & $.731^{* *}$ & $.660^{* *}$ & $.895^{* *}$ & $.816^{* *}$ \\
\hline & Sig. (2-tailed) & .000 & & .000 & .000 & .000 & .000 \\
\hline & $\mathrm{N}$ & 241 & 241 & 241 & 241 & 241 & 241 \\
\hline
\end{tabular}

It was observed from Table 5 that a strong and positive correlation exists between variables of the study. Thus, it is okay to say that organization's internal control environment (0.966), risk assessment (0.816), control activities (0.866), information and communication (0.837), and monitoring (0.911) are positively correlated with organizational performance.

\section{Multiple Regression Analysis}

A multiple regression analysis was conducted by the researcher to identify the relationship among the independent variables on organizational performance in telecommunications industry in South South and South East Nigeria. The statistical package for social sciences (SPSS) version 21 was applied to code, enter and compute the measurements of the multiple regressions for the study. The results are shown in the tables below.

Table 6

Model Summary ${ }^{\mathrm{b}}$

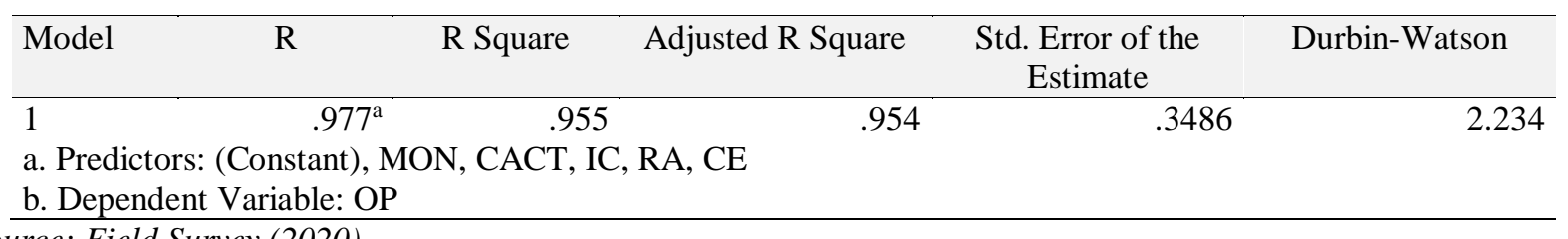

Source: Field Survey (2020)

Generally, the model summary table of the research questions 1-5 is as given in Table 4.5. It reveals the extent to which control environment, risk assessment, control activities, information and communication and monitoring accounted for change in organizational performance as seen by the adjusted $\mathrm{R}$ square, which shows that 95.4\%(0.954) of change in organizational performance is brought about by the joint predictive power of control environment, risk assessment, control activities, information and communication and monitoring. The DurbinWatson statistic is 2.234 which is above 2.00 and therefore indicates that the data is free from autocorrelation.

Table 7

ANOVA $^{\mathrm{a}}$ Table

\begin{tabular}{llrrrrr}
\hline Model & & Sum of Squares & df & Mean Square & F & Sig. \\
\hline & Regression & 601.589 & 5 & 120.318 & 989.994 & $.000^{\mathrm{b}}$ \\
1 & Residual & 28.560 & 235 & .122 & & \\
& Total & 630.149 & 240 & & & \\
a. Dependent Variable: OP & & & & & \\
b. Predictors: (Constant), MON, CACT, IC, RA, CE & & & & \\
\hline
\end{tabular}

Table 7 reveals that the $\mathrm{p}$ value for the F statistic $(.000)$ is $<.05$. This can be said to mean that at least one of the independent variables is a significant predictor of the dependent variable (organizational performance). 
Table 8

Multiple Regression Coefficients ${ }^{\mathrm{a}}$

\begin{tabular}{|c|c|c|c|c|c|c|}
\hline \multirow{2}{*}{\multicolumn{2}{|c|}{ Model }} & \multicolumn{2}{|c|}{ Unstandardized Coefficients } & \multirow{2}{*}{$\begin{array}{c}\begin{array}{c}\text { Standardized } \\
\text { Coefficients }\end{array} \\
\text { Beta }\end{array}$} & \multirow[t]{2}{*}{$\mathrm{t}$} & \multirow[t]{2}{*}{ Sig. } \\
\hline & & B & Std. Error & & & \\
\hline \multirow{6}{*}{1} & (Constant) & -.708 & .339 & & -2.087 & .038 \\
\hline & $\mathrm{CE}$ & .862 & .050 & .890 & 17.087 & .000 \\
\hline & RA & .252 & .037 & .242 & 6.837 & .000 \\
\hline & CACT & .096 & .030 & .092 & 3.240 & .001 \\
\hline & $\mathrm{IC}$ & .138 & .031 & .115 & 4.422 & .000 \\
\hline & MON & .312 & .064 & .307 & 4.911 & .000 \\
\hline
\end{tabular}

Source: SPSS version 21 output of field survey data, 2020

Result in Table 8 showed that the five components of internal control exerted a significant effect on organizational performance. The relative importance of the significant predictors was determined by the size of standard beta coefficient. Beta weight is useful because it uses a unit measurement that is same for all variables (Tabachnick and Fidel (2012). Thus, organization's internal control environment $(\beta=0.890, p=0.000)$ is the most important predictor of organizational performance.

\section{Test of Hypotheses}

Decision Rule: Reject null hypothesis (H0) if p-value is less than $0.05(5 \%)$ and if not, do not reject the null hypothesis. This result is seen below:

\section{Test of Hypothesis One}

$\mathrm{HO}_{1}$ : Organization's internal control environment has no significant effect on organizational performance in the telecommunications industry

From Table 8 , the sig. value is 0.000 . This value is less than the set value of 0.05 used as level of significance. Thus, the study rejected the null hypothesis $\left(\mathrm{H}_{0}\right)$ which stated that organization's internal control environment has no significant effect on organizational performance of telecommunications industry. The alternate hypothesis $\left(\mathrm{H}_{1}\right)$ that organization's internal control environment has a significant effect on organizational performance of telecommunications industry is therefore accepted.

\section{Test of Hypothesis Two}

$\mathrm{HO}_{2}$ : $\quad$ Risk assessment has no significant effect on organizational performance in the telecommunications industry From Table 8 , the sig. value is 0.000 . This value is less than the set value of 0.05 used as level of significance. Thus, the study rejected the null hypothesis $\left(\mathrm{H}_{0}\right)$ which stated that risk assessment has no significant effect on organizational performance in the telecommunications industry. The alternate hypothesis $\left(\mathrm{H}_{1}\right)$ that risk assessment has a significant effect on organizational performance in the telecommunications industry is therefore accepted.

\section{Discussion of Findings}

The findings of this study are hereby discussed and supported with relevant literatures thus;

\section{Organization's Internal Control Environment and Organizational Performance}

The significance value for organization's internal control environment is 0.000 from the coefficient table (Table 8 ). When compared with the study level of significance (0.05), organization's internal control environment has a significant and positive effect on organizational performance. The t statistics values on the other hand shows 17.087. It implies that organization's internal control environment has a positive relationship with organizational performance. One percent $(1 \%)$ movement in organizational performance is accounted for by standardized 
coefficients of $(\beta=0.890)$. The $\mathrm{r}$ value is 0.977 while, the $\mathrm{r}$-squared value of 0.955 depicts a near goodness of fit relationship between organization's internal control environment and organizational performance. The adjusted $r$ square value on its own part shows 0.954 (emphasizing non-spuriousity of variable) and this shows that movement in organizational performance is predicted by the variant in the model specification to the tune of $95.4 \%$ while other factors not included in the model specification has an effect of 4.6\%. A Durbin Watson value of 2.234 is also revealed from the analysis. The finding of this study is in line with Oppong et al. (2016) that the organization's internal control environment sets the tone of an institution and influences the control consciousness of its people. This is also in accordance with the claim of Mawanda (2008) that organization's internal control environment is the foundation for all other components of internal control, providing discipline and organizational structure. The study also follows the finding of Ayyash (2017) that found a significant and positive relationship between organization's internal control environment and financial performance of organization. The study is in line with Kinyua Gakure Gekara \& Orwa (2015) that found significant association between organization's internal control environment and financial performance.

\section{Risk Assessment and Organizational Performance}

The significance value for risk assessment is 0.000 from the coefficient table (Table 8 ). When compared with the study level of significance (0.05), risk assessment has a significant and positive effect on organizational performance. The t statistics values on the other hand shows 6.837. It implies that risk assessment has a positive relationship with organizational performance. One percent $(1 \%)$ movement in organizational performance is accounted for by standardized coefficients of $(\beta=0.242)$. The $r$ value is 0.977 while, the $r$-squared value of 0.955 depicts a near goodness of fit relationship between risk assessment and organizational performance. The adjusted $\mathrm{r}$ square value on its own part shows 0.954 (emphasizing non-spuriousity of variable) and this shows that movement in organizational performance is predicted by the variant in the model specification to the tune of $95.4 \%$ while other factors not included in the model specification has an effect of 4.6\%. A Durbin Watson value of 2.234 is also revealed from the analysis. This is in line with the finding of Njeri (2017) that risk assessment helps identify and mitigate risks before they happen which ensures smooth operation of business hence improving performance. The finding is also in accordance with Ayyash (2017) that found a significant and positive relationship between risk assessment and the financial performance of organization. The study also aligns with the study of Thuneibat et al. (2015) that found risk assessment to exert a significant and positive effect on organizational performance.

\section{Risk Assessment}

When asked how the organization identifies risks that affect the achievement of objectives. Interviewees responded that there are parameters put in place to identify the risk that are peculiar to the industry, and that these risks that are peculiar to the industry are looked at, and certain claims are made around them to ensure that they either are categorized as opportunities or as threat. The ones categorized as opportunities are developed to build the business, and the ones categorized as threat are ensured to be managed in other not to affect overall achievement of business objectives which includes growth and customer satisfaction. It was also added that there is a specific unit in charge of this called the business continuity unit that makes sure such risks are identified and managed to avoid having a negative impact on the organization, and also harness opportunities from this risk in building the business.

Some equally added that it is basically been approached by a careful study of pattern, trends and analysis of parameters that influences the overall achievement of set goals and objectives. While others said that their organization identifies risks that affect the achievement of objectives by going through what every staff has done and by scrutinizing every work before anything is submitted to the sky home. A given example of this was that, for SIM registration, confirmation will not be granted if it is noticed that the customer did not thumbprint as he/she should. Thus, the SIM will not work except it is regularized in line with the NCC guidelines provided for their organization.

Interviewees were asked if their organization have criteria for ascertaining the risks that are most critical to the organization. Given responses was that their organization identifies the risk and determine which ones are threats and which are opportunities. With that in place, they then look at how critical the risk is, the level of threat, and determine which is more critical and which begs for a more urgent attention. The risk that appears to be more dangerous is seen as the most critical to the organization. With this, they then set a parameter in place, and since they have a model for risk analysis in the organization where they look at all the risk affecting the business, and determine where to place them, they also look at the priorities and treat them base on how critical they are to the business. Others listed such criteria to include for example, in the course of SIM registration, there's a position the registrant 
ought to take, if the position is not properly maintained, the image will not be captured. While in the course of thumb printing, if it is not properly done, and if a finger is entered twice, the details will not be captured in the database. It was also added that the devices are designed in such a way that they must meet the laid down criteria.

Interviewees where asked the type of mechanisms put in place by their organization for mitigating critical risks that may arise during the course of doing business. It was said that there are fire extinguisher in strategic areas, provision of face masks and face shields and more which are used to mitigate against risk. Some added that in their organization, such mechanisms could be in form of trainings and courses, and also the adoption of legal risk motivation model. It was also added that there are models created to educate various stakeholders on how to go about reduction of various risk as it is associated with operations and with the telecom industry, and that guidelines are being put in place as contained in the organizational operations framework of the organization. Others agreed that in their organization, such mechanisms include auditing any issue that may have occurred that might make the business loose lots of revenue in the course of going against NCC rules.

\section{Conclusions}

Based on the findings in this study, the study affirmed that internal control has a positive and significant effect on organizational performance of telecommunications industry in South South and South East Nigeria. Thus, telecommunications industries that invested more on effective internal control systems are most likely to experience an improved overall performance as compared to those telecoms industries that had a weak internal control system. Also, the study affirms that telecommunications industry in South South and South East Nigeria has positive organization's internal control environment such as integrity and morale that management and employees safeguard to support administrative control and awareness. They also makes efforts to attract, develop, and retain the trusted and efficient employees which contribute in achieving the internal control objective, and they have internal control tools on human resources to evaluate the level of productivity, effectiveness and efficiency of its human resources.

\section{Recommendations}

- Organization's internal control environment showed a significant effect on organizational performance of telecommunications industry in South South and South East Nigeria. Management of firms in the telecommunication industries are recommended to further study the control environment on possible aspects they might have paid little attention to which might have impacted performance. Also, trusted and efficient employees that contribute in achieving the internal control objectives should be given room to share their ideas and expertise to other members in the organization in other to further improve the effect of control environment on performance.

- The study found that risk assessment have a significant effect on organizational performance of telecommunications industry in South South and South East Nigeria. The organizations are further encouraged to maintain their strategy implementation on risk assessment in other to have a sustained overall performance.

\section{References}

Adebanjo, D.O., Francis, L., and Tritos, T.M. (2013). A case study of supplier selection in developing economies: A perspective on institutional theory and corporate social responsibility. Supply Chain Management: An International Journal. 18. 10.1108/SCM-08-2012-0272.

Albert, O. and Byaruhanga, J. (2014). Effects of internal control systems on financial performance of sugarcane out grower companies in Kenya. IOSR Journal of Business and Management, 16(12): 62-73. Retrieved from www.iosrjournals.org

Amudo, A., Inanga, E.L. (2009). Evaluation of internal control systems: A case study from Uganda. International Research Journal of Finance and Economics; 1(27): 124-144

Ayyash, M.Y. (2017). The impact of internal control requirements on profitability of Palestinian shareholding companies Palestinian Banking Sector. A thesis submitted in partial fulfillment of the requirements for the degree of Master of Accounting \& Finance. The Islamic University-Gaza Research and Postgraduate Affairs Faculty of Commerce Master of Accounting \& Finance.

Badara, S. M. and Saidin, Z. S., (2013). Impact of the effective internal control system on the internal audit effectiveness at local government level: Journal of Social and Development Sciences 4(1):16-23.

Bakare, T. (2015). "MTN Nigeria CEO resigns as FG slashes fine to N674b". Guardian 
Bakare, Tonye (2015). MTN Nigeria CEO resigns as FG slashes fine to N674b. Guardian Newspaper.

Beeler, J. D., Hunton, J. E., \& Wier, B. (1999). Promotion performance of internal auditors: A survival analysis. Internal Auditing. 14:3-14.

Bongani, N., (2013). Application of internal controls in NGOs: Evidence from Zimbabwe, Journal of Finance and Accounting, 1(2): 39-47

Bowen, F. E., Rostami, M., \& Steel, P. (2010). Timing is everything: A meta-analysis of the relationships between organizational performance and innovation. Journal of business research,63(11), 1179-1185. https://doi.org/10.1016/j.jbusres.2009.10.014

Cahill, E. (2006). Audit committee and internal audit effectiveness in a multinational bank: A case study. Journal of Banking Regulation 7(1/2):160 - 179.

Campbell, S., \& Hartcher, J. (2009). Internal control for small business. Melbourne: CPA Austraila.

Chang, W., Park, J. E., \& Chaiy, S. (2010). How does CRM technology transform into organizational performance? A mediating role of marketing capability. Journal of business research, 63(8), 849-855. https://doi.org/10.1016/j.jbusres.2009.07.003

Committee of Sponsoring Organisations (COSO) framework, (2013). Internal Control - Integrated Framework: Internal Control over Financial Reporting: A Compendium of Approaches and Examples (Exposure draft).

COSO (2012). Internal Control Integrated Framework. Durham: American Institute of Certified Public accountants.

Dineshkumar, S. and Kogulacumar, P. (2013). Internal Control System and its impact on the Performance of the Sri Lanka Telecom limited in Jaffna District. International Journal of Advanced Computer Technology, 2(6):56-64

Donaldson, L. (1990). A rational basis for criticism of organizational economics: A reply to Barney. Academy of Management Review, 15:394-401.

Elenkov, D. S. (2002). Effects of leadership on organizational performance in Russian companies. Journal of Business Research, 55(6), 467-480. https://doi.org/10.1016/S0148-2963(00)00174-0

Elikwu, M (2008). Research Project Mode Easy: A simplified approach to write and defend a good research report. Lagos: Cin-Eight Publishers.

Fadzil, F. H., Haron, H., \& Jantan, M. (2005). Internal auditing practices and internal control system. Managerial Auditing Journal, 20(8):844-866.

Financial Nigeria (2017). Etisalat Nigeria rebrands to 9Mobile after UAE investors pull-out. Available on http://www.financialnigeria.com/etisalat-nigeria-rebrands-to-9mobile-after-uae-investors-pull-out-news1382.html

Frazer, L. (2012). The effect of internal control on the operating activities of small restaurants. Journal of Business \& Economic; 10(6): 361. https://doi.org/10.5539/ijef.v4n3p46

Gamage, C.T, Lock, K.L. and Fernando, A.A. (2014). A proposed reaserch framework: Effectiveness of internal control system in state commercial banks in Sri Lanka. International Journal of Scientific Research and Innovative Technology, 1(5): 25-44.

García-Morales, V. J., Jiménez-Barrionuevo, M. M., \& Gutiérrez-Gutiérrez, L. (2012). Transformational leadership influence on organizational performance through organizational learning and innovation. Journal of business research, 65(7), 1040-1050. https://doi.org/10.1016/j.jbusres.2011.03.005

Gray, I., (2008). The Audit Process: Principles, Practice and Cases. PatrickBon

Hales. (2005). Accounting and financial analysis in the hospitality industry, New York: Heinemann Publications.

Harris, L. C., \& Ogbonna, E. (2001). Strategic human resource management, market orientation, and organizational performance. Journal of business research, 51(2), 157-166. https://doi.org/10.1016/S0148-2963(99)00057-0

Hayali A, Dinc Y, Sarılı S, Dizman AS, Gundogdu A.(2013). Importance of Internal Control System in Banking Sector : Evidence From Turkey. Turkey: Marmara University. Retrieved from https://www.researchgate.net/publication/258258914

Hayali, A., Dinc, Y., Sarili, S., Dizman, A.S. and Gundogdu, A. (2013). Importance of internal control system in banking sector : Evidence from Turkey. Turkey: Marmara University, 2013. Retrieved from https://www.researchgate.net/publication/258258914

Hooks, K., Kaplan, S., Schultz, J., and Ponemon, L. (1994). Enhancing communication to assist in fraud prevention and detection.

Jacob, E.O. and Philip, A.O. (2016).Journal of Business and Management,18(10):80-85.

James, U. M., Godwin, E.I., Ojo, V. O. (2014). INTERNAL CONTROLS AND OPERATING PERFORMANCE OF SMALL BUSINESSES IN LAGOS METROPOLIS. Accountability \& Sustainable Business Development in Emerging Economies. July 9-11, 2014/O. A.U, Ile-Ife, Nigeria 
Janvrin, D.J., Payne, E.A., Byrnes, P., Schneider, G.P. and Curtis, M.B. (2012). The updated coso internal controlintegrated framework: Recommendations and opportunities for future research. Journal of Information Systems; 26(2): 189-213. https://doi.org/10.2308/isys-50255

Jensen, M. C. \& Meckling,W. H. (1976). Theory of the firm: Managerial behaviour, agency costs, and ownership Structure', Journal of Financial Economics.

Jussi, N and Petri, S. (2004). Does agency theory provide a general framework for audit pricing.? International Journal of Auditing, 8 (2):253-262.

Kansas State University, Internal Control Audit (n.d). Internal controls. Retrieved from https://www.kstate.edu/internalaudit/internal-controls/

Kinyua, J. K., Gakure, R., Gekara, M., \& Orwa, G. (2015). Effect of Internal Control Environment on the Financial Performance of Companies Quoted in the Nairobi Securities Exchange.

Kinyua, J.K. (2016). Effect of internal control systems on financial performance of companies quoted in the Nairobi securities exchange. (Unpublished PhD thesis). Jomo Kenyatta University of Agriculture and Technology, Kenya.

Kirsch,L.J (2002). Developing Common System Globally: The Dynamics of Control Infrastructure, Information Systems Research Issue 15,154 -167.

Kohler, T. (2003). Corporate accelerators: Building bridges between corporations and startups. Business Horizons, 59(3):347-357

Kothari, C. (2004). Research methodology, methods and techniques. 2nd edition, new age international publishers, New Delphi:

Li, S., Ragu-Nathan, B., Ragu-Nathan, T. S., \& Rao, S. S. (2006). The impact of supply chain management practices on competitive advantage and organizational performance. Omega, 34(2), 107-124. https://doi.org/10.1016/j.omega.2004.08.002

Lin, C., Chow, W. S., Madu, C. N., Kuei, C. H., \& Yu, P. P. (2005). A structural equation model of supply chain quality management and organizational performance. International journal of production economics, 96(3), 355365. https://doi.org/10.1016/j.ijpe.2004.05.009

Liu, Y., Combs, J. G., Ketchen Jr, D. J., \& Ireland, R. D. (2007). The value of human resource management for organizational performance. Business horizons, 50(6), 503-511. https://doi.org/10.1016/j.bushor.2007.07.002

Mawanda, S. P., (2008). Effects of internal control systems on financial performance in an institution of higher learning in Uganda: A case of Uganda Marytrs University, retrieved at https://www.academia.edu/4812543/effects_of_internal_control_systems_on_financial_performance

Ming, Y. and Wang, C. L. (2009). Bing Internal controls, auditing and forensic audit opinion financial theory and practice, Chinese.

Mire, H. A. (2016). Effects of internal control system on the organizational performance of remittance companies in Mogadishu, Somalia. IJRD-Journal of Business Management.

Mirinaviciene. (2014). Internal control and fraud prevention, New York: Keuka College.

Monday, J.U., Inneh, G.E. and Ojo, V.O. (2014). Internal controls and operating performance of small businesses in Lagos metropolis. Accountability \& sustainable business development in emerging economies. O. A.U, Ile-Ife, Nigeria.

Muhunyo, B. M. and Jagongo, A. O. (2018). Effect of internal control systems on financial performance of public institutions of higher learning in Nairobi City County, Kenya. International Academic Journal of Human Resource and Business Administration, 3(2):273-287

Ndungu, H. (2013). The effect of internal controls on revenue generation: A case study of the University of Nairobi Enterprise and services limited.

Newspaper.

Njeri, M.M. (2017). Effects of internal controls on the performance of multinational financial services companies in Kenya. A research project submitted in partial fulfilment of the award of the degree of masters of business administration of the University of Nairobi school of business.

Norton, R.F. (2016). COSO's new fraud risk management guidelines: What companies need to know.

Ntongo, V., (2012). Internal controls, financial accountability and service delivery in private health providers of Kampala district.

Ofori, W. (2011). Effectiveness of internal controls: a perception or reality? The Evidence of Ghana post company limited in Ashanti Region. Kwame Nkrumah University of science and technology

Olannye, A. P. (2006). Research methods for business: A skill building approach. Asaba: Pee Jen Publications. 
Oppong,M., Owiredu, A., Abedana, V.N. and Asante, E. (2016). The Impact of Internal Control on the Performance of Faith-Based NGOs in Accra. Research Journal of Finance and Accounting, 7(12):110-125

Peters. (1994). In Search of Excellence, New York: Harper and Row.

Ponte. (2009).Disclosure of social information by Brazilian companies according to United Nations indicators of corporate social responsibility, New York: UN.

ProQuest (2013). M-Cell is Now MTN Group Limited. PR Newswire: 1. 11 October 2002. Web.11.

Punch (2018). MTN pays N165bn of the N330bn fine, NCC says. Available on https://punchng.com/mtn-paysn165bn-of-the-n330bn-fine-ncc-says/

Saeidi, P. (2015), Investigating the Relation Between Internal Control System and Financial Performance of Telecommunication Company of Golestan Province, Multidisciplinary International Peer Reviewed Journal, 3(2):206-211, available at http://saussurea.org/

Saeidi, P., Shokoohi, M, Malekmahmoudi, S. K. (2015). Investigating the relation between internal control system and financial performance of telecommunication company of Golestan province, Multidisciplinary International Peer Reviewed Journal, 3(2):206-211, available at http://saussurea.org/

Short, J. C., \& Palmer, T. B. (2003). Organizational performance referents: An empirical examination of their content and influences. Organizational Behavior and Human Decision Processes, 90(2), 209-224. https://doi.org/10.1016/S0749-5978(02)00530-7

Singleton, T. W, Bologna, G. J, Lindquist, R. J., \& Singleton, A. J. (2006). Fraud auditing and forensic accounting (Third Edition). New Jersey: John Wiley \& Sons, Inc.

Tabachnick, B.G. and Fidell, L.S. (2012). Using Multivariate Statistics. 6h Edition, Person Education, Boston.

Taiwo, I. (2015). From Econet to Airtel: How many times has the telco changed hands? Available on https://techcabal.com/2015/10/06/from-econet-to-airtel-how-many-times-has-the-telco-changed-hands/

Theofanis, K., Drogalas, G and Giovanis, N. (2011). Evaluation of the effectiveness of internal audit in Greek hotel Business: International Journal of Economic Sciences and Applied Research, 4(1):19-34

Thuneibat, A. A., Rehaily, A. S., \& Basodan, Y. A. (2015). The impact of internal control requirements on profitability of Saudi shareholding companies. International Journal of Commerce and Management, 25(2): 196217.

Transparency International (2006). Corruption Perceptions Index. Retrieved from:.http://www.transparency.org/policyresearch/surveys. indices/cpi/2006

Umar, H. and Dikko, M.U. (2018). The effect of internal control on performance of commercial banks in Nigeria. International Journal of Management Research \& Review, 8(6):13-23. 